\title{
Microbiology Specimen Category
}

National Cancer Institute

\section{Source}

National Cancer Institute. Microbiology Specimen Category. NCI Thesaurus. Code C87899.

A classification of microbiology specimen data. 